\title{
Evaluasi Pembelajaran Nahwu dalam Bentuk Munaqasyah di PP Al-Luqmaniyyah Yogyakarta
}

\author{
Sri Guno Najib Chaqoqo \\ Program Doktor UIN Sunan Kalijaga Yogyakarta \\ sriguno.nc@gmail.com \\ DOI: http://dx.doi.org/10.18326/lisania.v1i1.17-36
}

\begin{abstract}
This study discusses the evaluation model of nahwu learning in munaqasyah form at Islamic Boarding School/Pondok Pesantren (PP) Al-Luqmaniyyah Yogyakarta. The analysis is based on the theoretical framework of nahwu learning evaluation conducted at formal school and Islamic school (madrasah). With a realistic analysis to the theoretical frameworks and real conditions, the evaluation models can be mapped out; the relevance and urgency of the model in the whole lesson at this Islamic Boarding School can be known. The study results show that the munaqasyah is only applied in Alfiyah Class because this book is considered as the highest level of nahwu subject at PP AlLuqmaniyyah. The implementation of munaqasyah to Alfiyah ibn Malik is done to measure achievement of the students (santri) in Alfiyah subject. The participation in Alfiyah continued until munaqasyah is considered as a standard that the students have followed the process gradually and completely.
\end{abstract}

Keywords: Evaluation, Nahwu Learning, Munaqasyah

\begin{abstract}
Abstrak
Penelitian ini membahas tentang model evaluasi pembelajaran nahwu dalam bentuk munaqasyah di Pondok Pesantren (PP) Al-Luqmaniyyah Yogyakarta. Analisa didasarkan pada kerangka teori mengenai evaluasi pembelajaran nahwu yang dilakukan di lembaga formal sekolah dan madrasah. Dengan analisa berbasis kerangka teori dan kondisi riil di lapangan bisa dipetakan model-model evaluasi tersebut; relevansi dan urgensi model itu dalam keseluruhan pembelajaran di Pesantren ini. Dari hasil penelitian di lapangan menunjukkan bahwa pelaksanaan munaqasyah hanya diterapkan untuk kelas Alfiyah dikarenakan kitab ini dianggap sebagai puncak dari pelajaran nahwu di PP AlLuqmaniyyah. Hal yang mendasari dilaksanakannya munaqasyah terhadap Alfiyah ibn Malik ini adalah untuk mengetahui capaian santri terhadap keikutsertaannya dalam pelajaran Alfiyah. Keikutsertaan dalam pelajaran Alfiyah hingga berujung munaqasyah ini dianggap sebagai ukuran bahwa yang santri telah mengikuti proses secara bertahap dengan sempurna.
\end{abstract}

Kata Kunci: Evaluasi, Pembelajaran Nahwu, Munaqasyah 


\section{Pendahuluan}

Evaluasi pembelajaran nahwu di pondok pesantren salaf pada umumnya, dilakukan dalam bentuk hafalan terhadap kaidah-kaidah nahwu yang berbentuk syair bait ataupun non bait. Teknik memberikan kewajiban hafalan menjadi alat kontrol terhadap tingkat ketekunan, intelektualitas, dan keseriusan santri terhadap pelajaran yang sedang ditempuhnya. Para pengajar, dalam hal ini kyai dan ustadz pesantren, menjadikan hafalan ini sebagai tolok ukur bagi santri terhadap pelajaran yang diberikannya. Seorang santri dianggap cerdas dan serius setelah menyetorkan sekian bait yang menjadi ketentuan setiap harinya.

Pada dasarnya, evaluasi pembelajaran terdiri dari dua suku kata, yaitu evaluasi dan pembelajaran. Evaluasi dalam bahasa asalnya, yaitu bahasa Inggris, berarti penilaian. Secara istilah evaluasi adalah proses dan kegiatan yang terencana untuk melihat apakah sebuah kegiatan yang direncanakan dan dilaksanakan iu sudah teriplementasi dengan baik atau berhasil. Kegiatan ini digunakan untuk mengambil kesimpulan dan darinya bisa disempurnakan kekurangan-kekurangan yang ada atau ditingkatkan jika sudah baik. Terkait dengan pembelajaran, maka evaluasi pembelajaran adalah perangkat dan instrumen guru dalam menilai apakah kegiatan pembelajaran sudah sesuai dengan yang diharapkan. Proses itu bisa dilihat dari indikator nilai ujian, atau perubahan perilaku peserta didik terhadap apa yang dipelajarinya.

Tujuan dari dilaksanakan evaluasi pembelajaran di antaranya adalah mengetahui kapasitas peserta didik dalam memahami materi pelajaran. Selain itu juga untuk melatih kecakpan dan keberanian siswa dalam mengingat pelajaran yang lalu. Dari dua hal itu kemudian juga bisa dilhat perubahan perilaku peserta didik terhadap materi pelajaran dari sebelum mengetahui hingga ketika mendalami. Proses ini akan memberikan gambaran dalam pemetaan siswa yang sudah paham dan yang belum paham, atau antara siswa yang cepat dan lambat dalam memahami materi pembelajaran. Hal-hal ini akan bermanfaat dalam membuat keputusan berdasarkan gambaran pelaksanaan dan hasil belajar yang telah dilaksanakan yang pada akhirnya bisa meningkatkan kualitas proses dan hasil pembelajaran.

Prinsip evaluasi pembelajaran adalah continuity, komprehensif, objektivitas, dan validitas. Continuitas adalah prinsip keberlanjutan, yaitu bahwa evaluasi haruslah 
dilaksanakan secara terus-menerus berkesinambungan untuk mendapatkan hasil yang sebenarnya. Prinsip komrehensif menekankan mengenai evaluasi secara keseluruhan dari aspek pendidikan, yaitu ranah berpikir, berperilaku atau bersikap, dan aspek ketrampilan atau kreativitas berfikir dan bertindak. Adapun prinsip objektivitas dimaksudkan sebagai keadilan, keseimbangan, dan proporsionalitas penilaian terhadap objek yang dinilai, dan yang terakhir adalah prinsip validitas, yaitu keshahihan suatu penilaian terhadap hasil belajar siswa.

Pembelajaran bahasa Arab di pesantren salaf, khususnya bidang nahwu dan sharaf, menjadi kajian yang unik jika ditilik dari perspektif kajian akademis di perguruan tinggi. Menjadi unik karena di tengah arus kuat atas tuntutan yang modern dalam pembelajaran bahasa di beberapa lembaga modern, pesantren salaf tetap mempertahankan tradisionalitas pembelajarannya. Ini bisa ditilik dari model pembelajaran bahasa Arab yang lebih menekankan pada aspek penguasaan bidang tertentu yaitu dengan apa ang dalam ilmu linguistik disebut dengan semantik dan sintaksis.

Tuntutan dunia akademis modern dalam pembelajaran bahasa Arab adalah penguasaan keempat keterampilan bahasa; menyimak, membaca, menulis, dan berbicara. Dalam bahasa Arab keempatnya diistilahkan dengan istima', qiraah, kitabah, dan kalam. Keempat keterampilan ini kemudian disistematisasi dalam metode all in one system atau istilah Arabnya adalah nadhariyah al-wahdah. Sistem ini tersubstitusi dalam beberapa kurikulum yang mendukung agar pembelajar bahasa Arab bisa menguasai keempat keterampilan melalui silabus yang dirancang sedemikian rupa sehingga targetnya adalah kemahiran berbahasa secara komplit; bisa membaca, menyimak, menulis, dan berbicara.

Sementara itu di banyak pondok pesantren salaf, termasuk lembaga yang akan diteliti ini, lebih menekankan pada penguasaan satu atau dua aspek kemahiran berbahasa, atau yang secara prinsip tidak ada tuntutan untuk menguasai keempat keterampilan tersebut. Kemahiran berbahasa yang banyak diajarkan adalah aspek penguasaan atas gramatika bahasa Arab, atau yang sering disebut dengan kemahiran atas nahwu dan shafar.

PP al-Luqmaniyyah yang mengidentifikasi diri dalam namanya sebagai pesantren salaf, secara geografis terletak di tengah kota di Daerah Istimewa Yogyakarta 
(DIY). Kota yang dikenal dengan modernitas sebagai kota pelajar. Banyak berdiri kampus, baik negeri maupun swasta. Sudah lazim diketahui bahwa dengan banyaknya kampus sebagai representasi lembaga pendidikan modern, masih ada lembaga pendidikan Islam bercorak pesantren yang dengan konsisten masih menjalankan sistem tradisionalnya, yang termanivestasi dalam kurikulum yang diterapkannya.

Dialektika dari pergumulan sebagai pesantren salaf di tengah masyarakat kota yang terkenal berpikiran kritis, rasional, liberal, dan modern, sangat menarik untuk diamati. Pergumulan itu misalnya dengan adanya sistem evaluasi munaqasyah yang dilaksanakan secara tersistem dengan baik. Munaqasyah selama ini dikenal di perguruan tinggi agama Islam sebagai ujian tertinggi yang harus ditempuh oleh calon sarjana strata satu. Penggunaan istilah ini tentu saja harus dipandang sebagai konvensi atas model evaluasi yang sangat jarang diterapkan di pesantren salaf. Model munaqosyah ini sangat unik dan menarik untuk dikaji lebih dalam dari perspektif dan posisi model evaluasi pembelajaran bahasa Arab, khususnya nahwu.

Berdasarkan hal tersebut, maka tulisan ini akan menjawab beberapa persoalan krusial yaitu; bagaimana pelaksanaan munaqasyah tersebut, mengapa munaqasyah hanya diberlakukan untuk kitab Alfiyah Ibn Malik, dan apa landasan yang mendasari pelakasanaan munaqasyah ini. Diharapkan dari pertanyaan itu akan terjawab beberapa persoalan antara lain; mendapatkan gambaran deskriptif tetang pelaksanaan munaqasyah ala pesantren salaf dengan santri mayoritas mahasiswa. Selain itu akan didapatkan penjeasan analitis teoritis mengenai reasoning pelaksanaan munaqasyah Alfiyah Ibn Malik. Selanjutnya akan didapatkan konsep epistemologis atas pelaksanaan munaqasyah atas Alfiyah Ibn Malik oleh para pembelajar (santri).

Signifikansi dari tulisan ini bagi pengembangan metodologi pembelajaran yang nantinya bisa dijadikan referensi oleh para pegiat pembelajaran bahasa Arab, khususnya unsur nahwu, baik di lembaga formal maupun informal adalah; akan didapatkan gambaran jelas mengenai dinamika dan perkembangan model evaluasi pembelajaran nahwu. Selain itu juga untuk mendeteksi perkembangan pondok pesantren salaf dalam merespon perkembangan zaman. Tidak kalah pentingnya adalah untuk mengetahui perbandingan perkembangan model evaluasi pembelajaran nahwu. 


\section{Metode Penelitian}

Tulisan ini berbasis penelitian lapangan yang dilakukan dengan mengumpulkan data lapangan. Penelitian ini akan menggunakan metode induktif berdasarkan deskripsi analitis dan humanis. Metode deskriptif dipersepsikan sebagai pembingkaian data berdasarkan apa yang diperoleh di lapangan kemudian diungkapkan kembali secara deskriptif. Analisis diskriptif dilakukan secara kritis berdasarkan kerangka teori tentang evaluasi pembelajaran, khususnya pada objek materi nahwu.

Untuk tujuan ini maka peneliti mengambil dua langkah yaitu pengumpulan dan analisis data. Untuk tahap pengumpulan data digunakan beberapa metode dan instrumen, di antaranya; Interview yang digunakan untuk memperoleh data mengenai sejarah pesantren, latar belakang santri, kurikulum yang dikembangkan, kualifikasi guru/ ustadz yang diidealisasikan. Kemudian observasi yang digunakan untuk melihat secara langsung keadaan pesantren yang diteliti, kegiatan-kegiatan harian, praktik pembelajaran, dan praktik harian santri. Terakhir adalah dokumentasi yang digunakan untuk mendokumentasikan berbagai hal terkait dengan pesantren pada umumna dan secara khusus dalam hal pembelajaran nahwu, di antaranya peraturan dan tata tertib pesantren, tata nilai yang dikebangkan berdasarkan tulisan-tulisan yang dipampang dipesantren, kitab yang digunakan dalam pembelajaran, dan mekanisme evaluasi. Untuk memperlancar metode tersebut maka digunakan instrumen berupa daftar dokumen yang dibutuhkan, catatan wawancara, gambar-gambar, kitab-kitab, dan perlengkapan pembelajaran (Arikunto, 1996: 151).

Setelah data yang dibutuhkan terkumpul dengan baik maka dilakukan anlisis terhadap data tersebut dengan beberapa metode, di antaranya secara deskriptif. Dengan metode ini ini diharapkan akan mendapatkan potret utuh atas berbagai fenomena yang menunjukkan indikator-indikator untuk membangun hipotesa dan asumsi awal mengenai temuan-temuan selanjutnya. Untuk mendapatkan potret utuh ini, peneliti menggunakan berbagai teori mengenai kurikulum, metodologi pembelajaran, ilmu pendidikan agar diperoleh analisa kritis terhadap hasil yang diamati di lapangan. Hal ini dilakukan dengan mengamati secara utuh aspek kelembagaan dan sistem pengajaran, materi, sistem evaluasi, test, dan penjenjangan kelas.

Sementara kajian humanis dibutuhkan untuk mendapatkan gambaran utuh mengenai pelaku dan praktisi kurikulum yang berkecimpung di dalamnya. Diharapkan 
epistemologi pengembangan kurikulum akan ditemukan dalam fenomena pemikiran dan hasil karya mereka. Ini untuk mendapatkan gambaran utuh mengenai perkembangan ayng simultan dari pengembangan kurikulum tersebut.

Berdasarkan uraian di atas, dapat disimpulkan bahwa langkah-langkah yang akan penulis lakukan adalah mengumpulkan data secara lengkap mengenai lembaga, kurikulum, kitab yang digunakan, metode pemebelajaran, penjenjangan kelas, sistem evaluasi, materi test, dan kualifikasi pengajar. Selain itu adalah data-data para pendiri, ustadz, pengasuh, dan pandangan mereka dalam pengembangan kurikulum pesantren. Setelah itu kemudian ditampilkan data teoritis sebagai landasan untuk mengkaji secara ilmiah dan sebagai pisau analisis bagi teori-teori pengembangan kurikulum. Diharapkan dari sini diperoleh kesimpulan yang komprehensif mengenai system dan model evaluasi pembelajaran nahwu melalui munaqasyah atas kitab Alfiyah Ibn Malik.

\section{Model Evaluasi Pembelajaran}

Evaluasi bermakna pada keseluruhan proses dan lebih menitikberatkan pada program pembelajaran, berbeda dengan penilaian hasil belajar. Penilaian hasil belajar adalah salah satu bagian dari evaluasi pembelajaran. Sebagai suatu program, evaluasi pembelajaran dibagi menjadi lima jenis (Arifin, 2014: 33), yaitu: pertama, Evaluasi perencanaan dan pengembangan. Sasarn utama dari proses evaluasi ini adalah memberikan bantuan tahap awal penyusunan program pembelajaran, yaitu kelayakan dan kebutuhan. Hasil dari evaluasi ini adalah meramalkan kemungkinan implementasi program dan tercapainya keberhasilan program pembelajaran. Tahap ini dilakukan sebelum program yang riil disusun dan dikembangkan.

Kedua, Evaluasi monitoring. Evaluasi ini diarahkan untuk menelaah mengenai ketercapaian sasaran secara efektif dan apakah pembelajaran terlaksana sebagaimana mestinya. Hasil dari ini adalah menelaah kemungkinan inefisiensi sumber-sumber dan menghindarkan waktu pelaksanaan pembelajaran.

Ketiga, Evaluasi dampak. Evaluasi ini diarahkan untuk mengetahui dampak yang ditimbulkan oleh program pembelajaran yang telah disusun sebelumnya. Hal ini diukur berdasarkan kriteria indikator keberhasilan ketercapaian pembelajaran.

Keempat, Evaluasi efisiensi-ekonomis. Sesuai sebutannya, evaluasi ini menitikberatkan pada penilaian tingkat efisiensi pelaksanaan program pembelajaran. 
Hal ini memerlukan komparasi antara jumlah biaya, tenaga, dan waktu yang dibutuhkan dalam suatu program pembelajaran dengan program lain yang memiliki tujuan sama.

Kelima, Evaluasi program komprehensif. Evaluasi ini dilakukan secara komprehensif sehingga diketahui keseluruhan proses dari perencanaan, pelaksanaan, monitoring, dampak, efektifitas dan efisiensi.

Pada tahap penilaian hasil belajar dibagi menjadi empat yaitu penilaian formatif, sumatif, diagnostik, dan penempatan. Penilaian formatif adalah penilaian ang dimaksudkan untuk memantau kemajuan belajar peserta didik selama proses belajar berlangsung dengan cara memberikan umpan balik (feed back) bagi penyempurnaan program pembelajaran. Proses ini adalah evaluasi berjalan yang berlangsung sangat detail karena kelemahan-kelemahan bisa langsung dilakukan perbaikan. Dari sini diketahui bahwa tujuan utama dari penilaian ini lebih kepada evaluasi untuk pendidik, dan bukan mengetahui kemampuan pembelajar. Dalam banyak kasus, penilaian ini pada kenyataannya tetap digunakan guru untuk mengetahui tingkat hasil belajar peserta didik, karena program perbaikan baru bisa terlaksana pada proses berikutnya setelah sebuah materi selesai, untuk tidak mungkin mengulanginya lagi pada tahun itu juga. Hasil penilaian ini akan bermanfaat bagi guru dan peserta didik. Bagi guru, akan diketahui sejauh mana bahan pelajaran dikuasai peserta didik, jika dikuasai baik maka tidak perlu mengulang, dan jika tidak dikuasai maka perlu diulang dengan strategi yang harus diubah atau uji coba strategi lagi. Selain manfaat ini, uru juga bisa memperkirakan hasil penilaian selanjutnya, yaitu pada tahap penilaian sumatif. Demikian juga bagi peserta didik, dengan mengetahui hasil penilaian ini maka peserta didik bisa memetakan bagian mana dari sebuah materi yang sudah dan belum dikuasai.

Penilaian sumatif adalah penilaian terhadap keseluruhan materi dan pengalaman belajar pada akhir periode pembelajaran (semester/ tahun), seperti ujian akhir semester dan ujian akhir nasional. Tujuannya adalah menentukan nilai akhir dari proses pembelajran dari beberapa materi pelajaran untuk selanjutnya digunakan untuk penilaian di rapor, berdasarkan hitungan yang ditentukan oleh pendidik. Materi soal tentu mencakup soal mudah, sedang, dan sulit (Arifin, 2014: 36).

Selanjutnya adalah penilaian penempatan, yaitu kegiatan pra tes untuk mengetahui kemampuan peserta didik dalam menguasai beberapa keterampilan dan pengetahuan untuk tujuan pemetaan bahan pealajaran, penempatan kelas, dan kesiapan 
peserta didik menghadapi program baru. Model soal yang digunakan relatif mudah karena penilaian ini digunakan untuk mengetahui kemampuan minimal yang dimiliki peserta didik.

Penilaian model terakhir adalah penilaian diagnostik yang digunakan untuk mengetahui kesulitan-kesulitan yang dihadapi peserta didik berdasar penilaian formatif sebelumnya. Soal-soal yang ditampilkan fokus pada kesulitan. Proses ini biasanya dilaksanakan sebelum pelajaran dimulai. Hampir mirip dengan penilaian penempatan, tujuannya adalah menjajaki kemampuan yang dimiliki sebelum memulai pembelajaran.

\section{Prinsip dan alat evaluasi}

Evaluasi pembelajaran pada prinsipnya merupakan tahap akhir dalam kegiatan pembelajaran. Kegiatan evaluasi dilakukan dengan pengukuran untuk menentukan penilaian tentang tiga fungsi yang harus dipenuhi, yaitu; pertama, Menilai efektivitas proses pembelajaran, yakni sampai sejauh mana kemampuan pebelajar mengerti tentang apa yang harus dimengerti. Kedua, menilai efektivitas prosedur pembelajaran. Maksudnya adalah sampai dimana pengajar berhasil mencapai tujuannya. Ketiga, menilai kemampuan pembelajar sesuai dengan standart yang harus dicapai.

Penilaian dalam evaluasi pembelajaran ada dua pendekatan antara lain; pertama, melalui apa yang disebut dengan Penilaian Acuan Normatif (PAN) yaitu penilaian yang membandingkan hasil belajar pembelajar terhadap hasil belajar pembelajar lain dalam kelompoknya (pendekatan apa adanya). Kedua, Penilaian Acuan Patokan (PAP) adalah penilaian yang membandikan hasil belajar pembelajar terhadap patokan yang telah ditetapkan sebelumnya (batas lulus atau tingkat penguasaan minimum). PAP ini bersifat tetap untuk kelompok pembelajar yang memperoleh pembelajaran yang sama.

Alat evaluasi ini dikenal dengan instrument evalausi. Penggunaan alat evaluasi ini adalah untuk mendapppatkan hasil yang lebih baik sesuai kenyataan yang di evaluasi. Ada dua jenis alat evaluasi dalam pembelajaran yaitu tulis dan non tulis.

\section{Munaqasyah nahwu: idealisme dan relevansi}

Ada beberapa istilah yang bermakna ujian dalam bahasa Arab, yaitu imtihân, ikhtibâr, dan munâqasyah ini. Dalam kamus al-Munawwir dan al-Munjid dijelaskan bahwa kata munâqasyah ( ) berasal dari akar kata naqasya-yanqusyu-naqsyan ( ) yang arti dasarnya adalah memberi warna serta menghias dengan aneka 
warna. Munaqasyah diartikan sebagai perdebatan, diskusi, dan dialog (Munawwir, 1997), (Makluf, 1997), (Atabik Ali, 1998). Di kamus al Munjid tidak ditemukan istilah munaqasyah, tetapi ada satu penjelasan dari akar kata ini yang berarti mendebat. Secara umum akar kata ini bermakna; memilah, memberi warna, megeluarkan, mendebat, menghitung. Analisa kebahasaan ini memberikan gambaran mengenai maksud dan tujuan dari munaqasyah yang telah baku bermakna ujian atau dialog. Di dalamnya terkandung makna mencari kejelasan dari diri orang yang diuji mengenai jenis pendapat, argumen yang disampaikan, warna atau corak dari materi yang diujikan, sehingga bisa diklasifikasikan dalam bagian-bagian yang jelas, serta mengidentifikasi orang yang diuji atau diajak dialog; di kelompok mana seorang mahasiswa dalam jenis kajian keilmuan melalui indikator skripsi, thesis, atau disertasi. Dalam perkembangannya, munaqasyah lebih dimaknai secara umum sebagai ujian akhir atas sebuah capaian karya tulis di perguruan tinggi agama Islam.

Semangat ujian akhir inilah yang nampaknya dipakai oleh penggagas munaqasyah pelajaran nahwu, khususnya dari kitab Alfiyah Ibn Malik di Pondok Pesantren Al-Luqmaniyyah. Sebagaimana diketahui oleh kalangan pesantren, kajian kitab Alfiyah adalah tingkat tertinggi dalam kajian nahwu setelah Jurumiyyah dan 'Imrithi. Dua kitab sebelumnya adalah pengantar atas istilah-istilah umum dalam nahwu dasar yang berguna untuk mempelajari nahwu di tingkat lanjut. Kajian kebahasaan setelah Alfiyah biasanya lebih kepada kajian sastra bahasa yang lebih dikenal dengan kitab Balaghah-nya. Menilik bahwa kajian Alfiyah merupakan tingkat tertinggi inilah wajar jika ujian akhirnya dinamai dengan Munaqasyah.

Selain dari sisi tingkat kesulitan, ujian ini dinamai munaqasyah dikarenakan bentuk ujiannya yang lebih mirip dengan sidang. Seorang santri disidang oleh tim penguji untuk mempertanggungjawabkan materi yang telah dipelajari dalam bentuk hafalan dan penjelasan makna yang terkandung.

Secara kronologis, munaqasyah diawali dengan pengumuman mengenai waktu pelaksanaan dan peserta yang akan mengikutinya. Pengumuman meliputi waktu dan tempat pelaksanaan serta kisi-kisi yang akan diujikan. Menurut penuturan dari ketua Dewan Pendidikan, materi ayng diujikan biasanya berkisar pada 13 bab dalam kitab Alfiyah; bab yang materinya paling sering digunakan dalam kalimat-kalimat di kitabkitab yang dikaji di PP Al Luqmaniyah dan umumnya pesantren salaf. 
Pada waktu yang ditentukan, penguji diundang ke Pesantren. Penguji berasal dari ustadz dan alumni yang dipandang mampu untuk menguji, karena tidak semua alumni mampu mengkaji kitab Alfiyah secara mendalam. Alumni yang memiliki kualifikasi demikian biasanya sudah memiliki bekal semejak belum masuk di Pesantren Al-Luqmaniyyah. Mereka telah lebih dulu mengikuti mata pelajaran pokok di pesantren sebelumnya. Saat mereka masuk di Pesantren Al Luqmaniyyah dan dipandang mampu mengajar teman-temannya, maka akan diberikan jadwal mengajar, dari kitab-kitab tipis hingga kitab tebal. Kitab-kitab tipis biasanya menjadi kajian di kelas-kelas awal walaupun tidak semua seperti itu. Pengabdian di pesantren inilah yang menjadi tolok ukur bagi alumni yang kelak layak menjadi penguji. Sejauh yang peneliti ketahui, hanya ada tiga alumni yang hingga kini masih "dipakai” untuk turut menguji munaqasyah ini, yaitu; Ustadz Burhan Majid, Ustadz Ade Supriyadi, dan Ustadz Imron Rosyidi. Adapun Ustadz dari dalam yaitu Ustadz Aminun dan Pengasuh.

Santri peserta munaqasyah akan hadir pada saat yang ditentukan secara bersamaan dari kelas tersebut. Berbeda dengan di perguruan tinggi agama Islam, munaqasyah tergantung dari penyelesaian karya tulisnya. $\mathrm{Di}$ pesantren $\mathrm{Al}$ Luqmaniyyah, munaqasyah adalah ujian akhir kelas tingkat empat atau kelas Alfiyah. Sehingga semua akan ujian munaqasyah secara bersamaan. Pada hari ujian dilaksanakan, santri akan antri bergiliran dipanggil satu per satu. Materi yang akan diujikan sudah disampaikan kisi-kisinya terlebih dahulu. Mekanisme ujian adalah santri megambil undian materi, berupa kertas yang telah ditulis didalamnya materi-materi sebagaimana kisi-kisinya tetapi lebih rinci, kemudian diserahkan kepada penguji dan penguji akan menanyai materi sebagaimana kertas yang didapatkan oleh peserta. Materi pertanyaan dalam bentuk; meminta kepada peserta untuk menghafal bab yang dikehendaki penguji. Bentuk menghafalnya adalah langsung pada materi atau dengan cara ustadz membaca awalnya dan peserta melanjutkan.

Selanjutnya, setelah hafalan bait nahwu Alfiyah ini, maka dilanjutkan petanyaan mengenai maksud dari bait nahwu tersebut. Materi dari keterangan bait nahwu diserahkan kepada santri, bisa dari buku terjemah, atau dari syarah Ibn Aqil; salah satu kitab pejelasan terhadap bait Alfiyah Ibn Malik.

Bentuk lain dari cara menguji adalah dengan dibalik pertanyaannya, yaitu penguji meyampaikan kaidah-kaidah nahwu umum atau penjelasannya kemudian 
ditanyakan pada bait mana kaidah itu terdapat. Kemudian santri peserta akan membaca hafalannya sesuai dengan kaidah tersebut. Menurut penuturan Ketua Dewan Pendidikan, Cholid Mawardi, para santri rata-rata lancar dalam menghafalnya. Ini dimungkinkan karena telah disampaikan kisi-kisi sebelumnya yang ditempel di papan pengumuman.

Pelaksanaan munaqasyah ini memakan waktu persantri sekitar 30 menit sehingga secara keseluruhan memakan waktu hingga tiga malam untuk 30 santri pada tahun ini. Pada tahun yang akan datang, seiring pertambahan jumlah santri, diperkirakan ujian munaqasyah ini akan diikuti oleh 72 santri, sehingga diperlukan alokasi waktu ujian sekitar 7 hari. Hal ini mengharuskan Dewan Pendidikan berfikir lebih banyak dikarenakan waktu yang lama; meyangkut ustadz penguji, dana bisyarah (honor) peguji, konsumsi, dan tempat. Ketua Dewan Pendidikan berkomentar singkat kepada peneliti mengenai ujian tahun yang akan datang:" Mumet kulo Pak" (saya pusing Pak; terkait pelaksanaan ini). Dewan Pendidikan yang terdiri dari santri senior ini arus memikirkan banyak hal terkait pelaksanaan ini. Mereka medapatkan sumberdana dari iuran para santri setiap bulannya. Tentu saja dana ini terbatas karena sudah digunakan untuk kegiatan rutin harian hingga bulanan. Tidak ada iuran khusus untuk kegiatan ini. Tradisi pesantren salaf memang tidak ada pembayaran tetek bengek (macam-macam) untuk pelaksanaan pendidikan. Dalam pelaksanaannya tidak ada istilah gaji untuk para ustdaz, yang ada adalah istilah bisyarah yang berarti bebungah, semacam uang sekedar untuk membantu beli rokok bagi para ustadznya. Hal ini dalam banyak hal terkait rasa pegabdian dan pengorbanan yang ingin diberikan kepada pesantren sebagai bentuk perjuangan mereka dalam menegakkan apa yang mereka yakini, yaitu agama Islam, melalui lembaga pendidikan.

Tradisi mau berkorban adalah sebuah keyakinan bagi banyak santri untuk mendapatkan ridha dari gurunya, dan dari ridha gurunya inilah diyakini pula bahwa ilmunya akan bermanfaat. Ilmu yang bermanfaat adalah capaian tertinggi orang yang belajar di pesantren. Ilmu bermanfaat tidak saja dalam bentuk memiliki santri yang banyak, tetapi sejauh mana ilmu tersebut diamalkan secara kontinyu dan sustainable.

Pada tahap selanjutnya, setelah santri selesai ujian, peserta bisa keluar ruangan dan dilanjutkan giliran santri lain. Mereka yang telah mengikuti ujian merasa lepas dari beban ujian ini. Meskipun hasil akhir dari ujian ini tidak ada nilai semacam ijazah, 
sertifikat, atau buku raport, tetapi bahwa mereka diuji oleh lima ustadz adalah hal yang sangat membanggakan. Seorang santri, Fatkhurrahman, yang peneliti temui mengungkapkan bahwa persiapan untuk diuji itu berbulan-bulan dalam menghafal. Meskipun tidak ada nilai yang diberikan, tetapi kemampuan menjawab ujian lisan secara langsung adalah sebuah kepuasan tersendiri baginya.

Dewan Pendidikan menjelaskan kenapa tidak ada semaca sertifikat atau ijazah dan raport, bahwa memang ujian munaqasyah ini tidak mengikat kepada jenjang kelas selanjutnya. Sehingga ujian munaqasyah ini benar-benar murni ujian yang dilaksanakan untuk kepentingan meningkatkan daya hafal santri terhadap kaidah-kaidah nahwu dalam kitab Alfiyah. Dahulu, sekitar tahun 2010 pernah nilai ujian ini mengikat, di mana peserta ujian yang tidak lulus maka tidak bisa melanjutkan jenjang selanjutnya. Tetapi justru hal ini menyulitkan Dewan Pendidikan dalam mengelola kelas karena keterbatasan ruang dan ustadz. Kesulitan ini diatasi dengan penekanan kepada para santri bahwa keberhasilan pembelajaran tidak seharusnya diukur dari angka-angkat, tetapi bagaimana proses belajar itulah yang terpenting. Sebagaimana disinggung pada pembahasan di bab terdahulu, bahwa sistem hafalan digunakan di banyak pesantren salaf untuk megukur kesungguhan mereka dalam belajar terhadap materi yang disampaikan di kelas. Tradisi hafalan ini mendominasi model transmisi ilmu dalam dunia Islam semenjak awal Islam tersebar di semenanjung dunia Arab. Diktum hadits mejadi terkategori shahih atau tidak di antaranya ditentukan oleh tingkat daya hafal dari pembawa hadits tersebut. Tradisi inilah yang menyebar dan digunakan di dalam transmisi keilmuan yang lainnya seperti ilmu sejarah.

Tradisi hafalan di pesantren salaf seperti ini dipertahankan untuk menghafal kaidah-kaidah nahwu sebagai pembelajaran. Betapapun kalangan ahli pendidikan liberal mengkritik model ini sebagai memperlakukan anak sebagai robot yang bertugas menghafal materi pelajaran, tetapi di pesantren menjadi kegiatan dan tugas yang dipertahankan. Metode hafalan ini dipandang sangat efektif untuk mengukur tingkat keseriusan santri dalam mengikuti pembelajaran. Selain itu, daya hafal yang tinggi akan menambah point otoritas keilmuan seseorang kelak ketika pulang dari pesantren dan kembali ke masyarakat. Masyarakat akan menganggap santri tersebut kompeten dalam keilmuannya bisa dilihat dari kemampuan menghafal diktum-diktum kaidah keilmuan yang dibutuhkan dalam agama Islam. Latihan menghafal nahwu ini setidaknya menjadi 
langkah awal untuk meghafal kaidah-kaitah aturan fiqih atau ilmu lain seperti hadits atau al Qur'an. Banyak orang yang dianggap berhasil secara keilmuan dengan berbekal hafalan yang kuat.

\section{Munaqasyah; Relevansi dan Urgensinya di PP Al-Luqmaniyyah}

Ujian munaqasyah menjadi puncak dari ujian jenjang kelas yang dilalui oleh para santri di PP. Al Luqmaniyyah karena tidak akan ada lagi sesi hafalan pada kelas setelahnya, yaitu kelas takhtim atau tahun kelima. Kelas takhtim adalah semacam kelas advance yang mengkaji kitab-kitab yang dianggap lebih berat terkait kajian, tidak saja fiqih tetapi sudah lebih luas yaitu kitab ushul fiqih serta tafsir. Kajian-kajian seperti ini meniscayakan penguasaan materi dasar yang utamanya adalah materi nahwu ini. Sebagaimana dijelaskan pada bab terdahulu bahwa otoritas keilmuan seseorang terhadap agama Islam ditentukan ole materi pemahaman nahwu sebagai dasarnya. Kajian ushul fiqih sangat cocok bagi santri yang telah menamatkan kajian materi nahwu ini. Pada saatnya kelak, para santri yang telah lulus kajian nahwu Alfiyah Ibn Malik, diharapkan mampu menelaah lagi kitab-kitab standard pesantren yang belum sempat diajarkan di pesantren. Era teknologi informasi seperti ini, otoritas keilmuan seseorang tidak bisa ditentukan oleh dasar-dasar dangkal dari proses salin cetak (copy-paste) materi dari internet untuk menjawab berbagai persoalan keummatan. Proses pemerole

han keilmuan dari internet bukanlah proses yang dibenarkan oleh pesantren karena tidak ada ketersambungan ilmu dengan mata rantai di atasnya.

Dalam konteks ini maka munaqasyah menemukan relevansinya sebagai salah satu aspek penilaian yang menjadi dasar evaluasi pembelajaran, khususnya dalam bidang nahwu. Seorang ustadz akan mengetahui sejauhmana daya serap dan daya hafal santri dalam melakukan proses pembelajaran di Pesantren al Luqmaniyyah. Selain itu bagi ustadz sendiri menjadi tantangan dalam lebih mendalami perkembanganperkembangan pemikiran santri. Secara kelembagaan juga akan diketahui sejauhmana efektifitas pembelajaran nahwu ini bisa berjalan dan dipertahankan. Ulasan mengenai relevansi dan urgensi mengenai muanqasyah akan ditulis pada beberapa paragraf berikut ini.

Sebagaimana dijelaskan pada bab dua, test adalah salah satu instrumen evaluasi secara keselurhan. Itu artinya pelaksanaan test hanyalah sebagai salah satu alat ukur terhadap pelakasanaan evaluasi yang dilakukan berkala. Ada kekhasan bagi pesantren 
yang secara umum sangat independen bila dibanding dengan lembaga pendidikan formal. Evaluasi pembelajaran lebih megacu pada refleksi internal satuan lembaga pesantren itu sendiri yang tidak berimplikasi formal terhadap jalannya pembelajaran di pesantren. Evaluasi lebih dimaknai sebagai refleksi terhadap pembelajaran yang dilakoni oleh si santri. Bagi kebanyakan ustadz, ada dan tidak ada test, kewajiban mereka telah dilaksanakan dan sangat teruji ketulusannya. Ketulusan ini dalam banyak hal melampaui refleksi evaluatif dari luar diri ustadz tersebut. Jelasnya, siapa yang bakal berani mengevaluasi, baik secara kuantitatif maupun kualitatif, terhadap ustadz yang rela mencurahkan tenaga, pikiran, dan waktu untuk mengajar secara karitatif. Reward financial yang mereka terima lebih sebagai pengakuan akan ketulusan mereka, dan reward financial ini dipandang tidak akan sebanding dengan pengorbanan mereka. Setidaknya inilah yang disampaikan oleh pengurus kepada penulis dalam sebuah obrolan di Pesantren itu.

Pesantren sebagai sub-kultur lebih sering melakukan evaluasi melalui mekanisme yang sama sekali berbeda dalam beberapa hal. Pesantren merupakan proyeksi dari diri pengasuhnya, sehingga melakukan evaluasi di pesantren harus dilakukan secara seksama dan peuh pertimbangan. Dalam konteks ini maka evaluasi, sekali lagi, lebih berorientasi kepada self treatment santri dalam mengikuti pembelajaran di Pondok.

Program evaluasi yang diadakan di PPLQ ini secara teknis diadakan dalam bentuk ujian semester sesuai kalender pesantren yang dimulai pada bulan syawal. Sehingga untuk semester pertama diadakan pada bulan Shafar akhir menjelang bulan Rabi'ul Awwal atau bulan Maulud. Soal ujian dibuat oleh masing-masing ustadz dalam bentuk soal essay terhadap materi pelajarannya. Pelaksanaan ujian diadakan dalam ruang kelas sesuai kelasnya masing-masing, dan tidak dipisahkan atau dipindah kelas sebagaimana ujian di kampus atau di sekolah, dengan ustadz mata pelajaran itu sendiri yang mengawasi hingga mengoreksi dan memberi nilai.

Hasil ujian tidak diberikan dalam bentuk raport tetapi hasil pekerjaan di lembar jawab itulah yang diberikan. Tidak ada istilah yudisium untuk kenaikan kelas karena secara otomatis setiap santri akan naik kelas. Ini menegaskan kekhasan pesantren dalam melakukan test. Santri diharapkan bisa merefleksi hasil pembelajarannya dalam memahami kitab. 
Evaluasi melalui test sebagai instrumennya, tidak akan diberlakukan terhadap ustadz dalam konteks untuk mengevaluasi model pembelajarannya oleh institusi, dalam hal ini dewan pendidikan. Megevaluasi ustadz, apalagi yang sudah senior mengandung beban psikologis dan dipandang tidak etis. Hal ini lebih kepada tata nilai kepesantrenan yang secara affirmatif sangat dipegangi oleh dewan pendidikan dan pengasuh. Hal paling mungkin adalah evaluasi oleh pengasuh pesantren kepada ustadz. Hanya saja dalam konteks Pesantren al Luqmaniyyah ini, semenjak pengasuh awal meninggal tahun 2012, para santri merasa belum mendapatkan pengganti, meskipun Ibu Nyai, istri pegasuh terdahulu, sudah menikah lagi. Uniknya, yang menikahi Ibu Nyai adalah adik dari suami terdahulu yang meninggal. Peran pengganti ini belum sepenuhnya bisa berfungsi secara baik dikarenakan, di antaranya, tidak adanya komunikasi yang intens antara pengasuh (Kyai saat ini) dengan para santri, khususnya para pengurus dan ustadznya. Komunikasi yang diharapkan oleh pegurus dan ustadz dengan pengasuh barunya adalah komunikasi untuk mendalami berbagai program yang harus dilanjutkan sesuai dengan visi pengasuh sebelumnya.

Jangkauan ke persoalan pribadi lebih dinilai mengena daripada ujian formal di kelas karena sisi kepribadian ini yang cenderung diutamakan. Seorang kyai akan lebih bisa megarahkan santri setelah mengetahui kepribadiannya kepada aspek recovery dan restorasi perilaku sehingga kelak diharapkan ilmu yang didapatkan di kelas lebih bisa memberikan kemanfaatan dalam hidupnya.

Konseling secara pribadi sangat dianjurkan dalam ilmu bimbingan konseling dalam konteks memberikan pemahaman yang lebih dalam memilah persoalan sehingga akan lebih jeli dalam melihatnya. Kemampuan untuk melihat persoalan dengan kemauan seorang konselor mendengar dan berempati diyakini lebih efektif dalam membantu mengatasi persoalan-persoalan konseli. Praktik ini dipesantren al Luqmaniyyah sudah dijalankan secara alami antara santri dan kyai. Keadaan ini dimungkinkan karena jumlah santri yang tidak terlalu banyak dan masih memungkinkan kyai memantau secara langsung kegiatan santri satu persatu.

Melihat proses munaqasyah dan lingkungan kehidupan santri di PP. Al Luqmaniyyah, maka bisa dikatakan bahwa munaqasyah adalah entitas evaluasi yang sangat bermakna meskipun tidak sama dengan proses evaluasi pada umumnya di pondok pesantren salaf. Di pesantren salaf pada umumnya, evaluasi lebih bermakna 
secara formal untuk kepentingan pengukuran dan peilaian santri itu sendiri. Evaluasi ini tidak begitu dominan maknanya bagi ustadz atau lembaga pesantren secara keseluruhan.

\section{Evaluasi Komprehensif di Pesantren}

Evaluasi komprehensif dalam hal ini mengacu pada evaluasi keselurhan bagi santri oleh pegasuh dan masyarakat. Sebagaimana disinggung di atas, cita-cita tertinggi dari pegasuh (kyai) terhadap anaknya adalah harapan bahwa kelak santrinya akan memiliki ilmu yang bermanfaat. Ilmu bermanfaat ditandai dengan ilmu yang diamalkan dan ditularkan kepada orang lain, minimal keluarganya kelak ketika sudah menikah. Komponen manfaat juga harus berimplikasi kepada kepatuhan dan doa kepada orang tua di rumah.

Proses dalam melahirkan ilmu yang bermanfaat ini dilalui di Pesantren al Luqmaniyyah dengan pembelajaran aktif dan penekanan pada apa yang disebut riyadhah; latihan mental melalui praktik puasa atau yang lainnya. Khusus di pesantren ini, riyadhah ditekankan pada praktik tidak makan makanan yang berbahan nasi. Praktik ini dilaksanakan selama tiga tahun dengan dasar kesadaran oleh santri sendiri kepada kyai. Meskipun berbasis kesadaran, namun hanya sedikit dari santri yang tidak melaksanakannya. Praktik riyadhah ini diyakini akan berdampak panjang ketika santri sudah tidak di pondok lagi. Pengasuh sering menyampaikan bahwa degan riyadhah maka hidup mulia akan lebih mudah dicapai. Praktik riyadhoh lebih mementingkan aspek batin daripada aspek fisik. Proses asketik seperti ini sangat biasa dalam dunia Islam sufistik. Dalam sebuah kesempatan, kyai berujar: "mangan sega marai rosa, orang mangan sega marai kuasa" (makan nasi akan membuat seseorang kuat perkasa, tetapi dengan meinggalkan nasi akan membuat seseorang berkuasa). Cita rasa kata-kata ini memang akan terasa mendalam dalam bahasa Jawa. Karena makna kuasa lebih mengena daripada bermakna rosa.

Selain bentuk riyadhah, penekanan kemanfaatan ilmu juga diraih melalui kepatuhan dan penghormatan kepada guru. Lagi-lagi hal ini lebih akrab dalam dunia sufistik. Pesantren salaf memang memiliki coran Islam sufistik di Indonesia. Riyadhah dan kepatuhan kepada ustadz sebagai mursyid adalah indikatornya. Kepatuhan kepada guru dilaksanakan pasca kontrak penyerahan orang tua kandung kepada pengasuh. 
Sebagaimana disinggung di atas, penyerahan kepada pengasuh dilakukan saat pendaftaran santri oleh orang tuanya.

Kepatuhan kepada kyai, sebagai representasi kepatuhan kepada guru, adalah manifestasi dari pengagungan ilmu itu sendiri. Guru dianggap sebagai faktor penting bagi keberlangsungan pencarian ilmu sekaligus ketenangan batin bagi seorang santri. Dalam salah satu tulisan Abdur Munir Mulkhan, watak komunalistik orang Indonesia pada umumnya, kesalehan seseorang diukur dari persandaran dan asosiasi seseorang itu kepada orang saleh (Mulkhan, 2004).

Kepatuhan kepada kyai adalah ujian terberat bagi seorang santri karena kyai, sebagai orang tua yang baru datangnya dibanding orang tua sendiri. Jika kepatuhan kepada orang tua kandung masih bisa diselingi dengan bercanda dan bermain bersama, keaptuhan kepada seorang kyai adalah proses berat yang harus dilalui seorang santri. Tidak terkecuali di Pesantren al Luqumaniyah ini. Seorang santri dianggap melewati masa-masa krusial dengan tingkat kepatuhannya kepada kyai sekian tahun dari masa ia berada di pesantren tersebut. Sikap ini akan dianggap konservatif bagi yang tidak setuju dengan pandangan ini. Jangankan kepada guru sendiri, kepada imam mazhab dan ulama-ulama Ilsam kenamaan, sikap yang dikembangkan adalah sikap kritis, bahasa halus untuk sikap yang memandang pendapat ulama dengan sikap "selalu curiga". Sikap kritis yang memandang pendapat orang lain dengan selalu curiga ini sangat dijauhi di pesantren untuk diterapkan kepada guru atau kyai mereka. Ini berlaku pula dalam memandang pendapat-pendapat para ulama yang tertuang dalam kitab-kitab yang dikaji. Sikap paling jauh adalah sikap untuk memilih sekian pendapat yang terbentang dalam kitab-kitab yang dikaji tanpa harus memandang rendah satu pendapat dibanding lainnya.

Para santri di PP al-Luqmaniyyah meyakini bahwa untuk mendapatkan otentisitas keislaman, atau dalam bahasa yang lain adalah kemurnian Islam, tidak bisa dilakukan dengan cara kembali ke al Qur'an dan Al Sunnah secara langsung. Ada perantara-perantara yang berperan dalam mentransfer keilmuan dari generasi ke generasi. Satu generasi mengerti ajaran Islam dari generasi sebelumnya, begitu seterusnya hingga tersambung kepada Nabi Muhammad. Sikap ini akan lebih memberikan eklektisitas praktik Islam dibanding misalnya degan slogan kembali ke al Qur'an dan Hadits dengan cara "hanya" membaca keduanya. Bacaan teks tidak akan 
memberikan pegertian, pemahaman, dan gambaran yang lebih baik tanpa melalui pengalaman langsung dengan guru-gurunya. Transmisi dari guru kepada guru hingga ke atas inilah yang disebut mata rantai keilmuan. Jika slogan kembali kepada al Qur'an dan al hadits tidak dimaknai hati-hati, yang terjadi adalah keterputusan mata rantai ini karena peran guru telah termarginalkan oleh ketidakbutuhan terhadap guru mereka.

Kepatuhan kepada guru di Pesantren al-Luqmaniyyah mewujud dalam kesadaran mereka mengikuti program pesantren dalam jadwal harian yang telah dibuat. Pelanggaran terhadap satu atau dua peraturan dianggap sebagai ketidakpatuhan kepada kyai melalui aturan-aturan tata tertibnya. Hal ini logis karena program pesantren adalah satu kesatuan antara program satu dengan yang lainnya. Selain kepatuhan kegiatan juga tentu saja kepatuhan dalam praktik riyadhah berupa mujahadah pagi dan sore serta puasa ngrowot sebagaimana dijelaskan di atas.

\section{Kesimpulan}

Proses pelaksanaan munaqasyah adalah ujian lisan yang melibatkan 5 penguji dan satu orang yang diuji. Penguji memberikan pertanyaan-pertanyaan terkait dengan materi-materi nahwu khususnya yang ada dalam kitab Alfiyah ibn Malik. Materi yang ditanyakan telah disampaikan kisi-kisinya pada pengumuman yang disampaikan oleh Dewan Pendidikan. Penilaian dilakukan secara langsung dan didokumentasikan dalam rekap nilai yang kemudian disimpan oleh Dewan Pendidikan untuk digunakan sebagai dasar pengumuman berikutnya. Nilai dalam munaqasyah ini tidak berimplikasi formal terhadap jenjang selanjutnya. Namun bagi peserta, keikutsertaan ini menjadi prestise tersendiri dengan persiapan yang dilakukan jauh sebelumnya dalam bentuk hafalanhafalan dan latihan menguraikan serta menghubungkan dalam praktik di kitab-kitab yang mengiringi materi nahwu.

Pelaksanaan munaqasyah hanya diterapkan untuk kelas Alfiyah dikarenakan kitab ini dianggap sebagai puncak dari pelajaran nahwu di Pesantren Al Luqmaniyyah. Meskipun pasca Alfiyah masih ada pelajaran terhadap kitab-kitab besar lanjutan, tetapi Alfiyah menjadi simbol dari capaian pembelajaran penting di Pondok Pesantren Al Luqmaniyyah. Hal yang mendasari dilaksanakannya munaqasyah terhadap Alfiyah ibn Malik ini adalah untuk mengetahui capaian santri terhadap keikutsertaannya dalam pelajaran Alfiyah. Keikutsertaan dalam pelajaran Alfiyah hingga berujung munaqasyah 
ini dianggap sebagai ukuran bahwa yang bersangkutan mengikuti proses secara bertahap dengan sempurna.

\section{Daftar Rujukan}

Arifin, Zainal. Evaluasi Pembelajaran; Prinsip, Teknik Prosedur (Vol. 6). Bandung: Remaja Rosdakarya, 2014.

Arikunto, Suharsimi. Prosedur Penelitian. Jakarta: Rineka Cipta, 1996

Asrori, Imam, M. T., M. Ainin. Evaluasi dalam Pembelajaran Bahasa Arab. Malang: Misykat. 2012.

Atabik Ali, A. Z. M. Kamus KontemporerArab-Indonesia (Vol. 3). Yogyakarta: Yayasan Ali Maksum Pondok Pesantren Krapyak, 1998.

Azra, Azyumardi. Pendidikan Islam Tradisi dan Modernisasi Menuju Milenium Baru (Vol. IV). Jakarta: Logos Wacana Ilmu, 2002.

Chaqoqo, Sriguno. Model Pembelajaran Nahwu di Pondok Pesantren Salaf; Kajian di Pondok Pesantren Nurl Qur'an Magelang. Field Research. IAIN Salatiga. Salatiga. 2015.

Efendi, Ahmad Fuad. Metodologi Pengajaran Bahasa Arab. Malang: Misykat. 2005.

Hafidz, Muhamad. Pembelajaran Bahasa Arab; Sebuah Pendekatan Metodologi. Salatiga: STAIN Salatiga Press, 2012.

Hermawan, A. Metodologi Pembelajaran Bahasa Arab. Bandung: Remaja Rosda Karya, 2014.

Ibrahim, R. Bertahan di Tengah Perubahan. Yogyakarta: Sibuku, 2015.

Kane, T. J., Kerr, K. A., Pianta, R. C., \& Measures of Effective Teaching Project. Designing teacher evaluation systems : new guidance from the measures of effective teaching project (First edition. ed.).

Madjid, N. Bilik-Bilik Pesantren. Jakarta: Paramadina, 1997.

Mahmud, N. M. r. Khashaish al 'Arabiyyah Wa Tharaiqu Tadrisiha. Beirut: Dar al Nafais, 1998.

Mahmud, S. U. Ta'lim wa Ta'alum Maharat al Tadris fi 'Ashr al Ma'lumat. Kairo: Alam al kutub, 2005. 
Makluf, L. Al Munjid. New Delhi: JMC India Publisher. 1997.

Mulkhan, A. Munir. Syekh Siti Jenar: Makrifat Burung Surga dan Ilmu Kasampurnan. Yogyakarta: Kreasi Wacana, 2004.

Munawwir, A. W. Al Munawwir; Kamus Arab-Indonesia Terlengkap. surabaya: Pustaka Progressif, 1997.

Subiyakto dan Nababan, S. U. Metodologi Pengajaran Bahasa. Jakarta: Gramedia pustaka, 1993.

Sudaryono. Dasar-dasar Evaluasi Pembelajaran. Yogyakarta: Graha Ilmu, 2012.

Supranata, S. Panduan Penulisan Tes Tertulis. Bandung: Remaja Rosdakarya, 2004.

Urbina, A. A. S. Psycological Testing. New Jersey: Prentice-Hall, Inc Company, 1997. 